\title{
The Development of The NonPRofit SeCtor in RuSSian Regions: MAIN Challenges
}

\author{
Anna Artamonova \\ Vologda Research Center of the Russian Academy of Sciences, \\ Department of Editorial-and-Publishing Activity and Science-Information Support, \\ 56A, Gorky str., 160014, Vologda, Russia \\ e-mail: artamonova.ast@gmail.com
}

\begin{abstract}
This article aims at identifying the main barriers hindering development of the nonprofit sector in Russian regions. The research is based on the conviction that the development of the nonprofit sector is crucial for the regional socio-economic system and depends upon civic engagement. The results of an analysis of available statistical data and a sociological survey conducted in one of the Russian regions reveal that the share of the Russians engaged in volunteer activities is low; over $80 \%$ of the population do not participate in public activities; less than $10 \%$ have definite knowledge of working nonprofit organizations. The study allowed identifying three groups of the main barriers and formulating some recommendations for their overcoming.
\end{abstract}

\section{Keywords}

Russia; Nonprofit sector; Nongovernmental organization; Civic participation; Civic engagement.

\section{Introduction}

Sustainable development of Russian regions requires the fullest use of their internal potential. As the public and private sectors cannot meet all demands concerning the provision of high living standards for all groups of the population, it is necessary for local authorities to find new opportunities for effective and mutually beneficial cooperation with other economic actors. In Russian regions, in this regard a new trend becomes evident - government starts to pay more attention to organizations of the third (nonprofit) sector.

While the importance of the nonprofit sector has been acknowledged worldwide, it is still at the stage of formation and development in Russia. Governmental bodies work at improving the regulatory and legal framework underlying the sector $[1 ; 2]$ and introduce various support mechanisms [3; 4]. According to Knyazeva [5, p. 141], the impetus for the development of the nonprofit sector was the adoption of several laws regulating its activities, which allowed systemizing and legitimizing the main characteristics of its civil status. In recent years, the number of research papers describing the potential of the nonprofit sector in regional economy has been constantly increasing. However, the research focus is mainly on general trends and problems related to the adoption of new models of interaction between governmental and nonprofit organizations see e.g. $[6 ; 7 ; 8 ; 9 ; 10]$.

In the world academic discourse scholars have come to the conclusion that the potential of the nonprofit sector is realized in a limited form. According to Salamon [11], the reason lies in four main "voluntary failures": philanthropic insufficiency, i.e. inability to generate reliable resources for an adequate response to community needs; philanthropic particularism, i.e. the tendency to focus on particular subgroups leaving less "deserving" groups to public 
institutions; philanthropic paternalism resulting in situations when the nature of voluntary sector comes to be shaped by those providing resources; and philanthropic amateurism which means amateur approaches to serious problems and lack of professionalism. These failures are still characteristic for the activities of the nonprofit sector. As Enjolras et al. [12, pp. 131-141] note, lack of financial and human resources, insufficient level of professional and technical expertise are considered among the main barriers hindering the development of the sector and limiting its ability to promote civic engagement. On the contrary, nonprofit organizations play a distinctive role in encouraging civic engagement within local communities [13]. We assume that this is a reciprocal process, and the level of people's engagement has an impact on the size and efficiency of the nonprofit sector. Thus, when analyzing the development of the nonprofit sector in Russian regions, we focus on people's engagement in its activities.

\section{$1 \quad$ Research Objective}

The purpose of this study is to determine the main barriers hindering the development of the nonprofit sector in Russian regions. The research is based on the assumption that the development of the nonprofit sector depends upon civic engagement. This dictates the necessity of special scientific attention to this phenomenon. The article adopts a notion of civic participation rooted in Nakamura's [14] understanding of vital engagement: a type of involvement in which an individual experiences

"enjoyed absorption over a sustained amount of time, activity [that] provides a link to the individual and the world, and [is] meaningful and significant to the individual".

The article's design includes a short description of general development features characteristic for the Russian nonprofit sector and focuses on determining the main challenges the sector faces.

\section{$2 \quad$ Methods}

The methodology of the study is based on analytical and system approaches, methods of comparative analysis and description. First of all, we analyzed scientific papers and legal acts concerning the functioning of the nonprofit sector and its role in the social sphere. The research information base was made up of data from specialized portals of U.S. Bureau of Labor Statistics, the Ministry of Justice of the Russian Federation, the Ministry of Economic Development of the Russian Federation, the Federal State Statistics Service, and the websites of the local governments of Russian regions. Systematization of the data obtained allowed us to draw the conclusions presented in the article. The study is based on the experience of foreign countries in which public administration (including the nonprofit sector) is successfully implemented on the basis of the principle of subsidiarity, which involves solving social problems at the lowest level - in the family or local community [15]. In a slightly modified form, this principle becomes relevant in modern Russian conditions, when there is a tendency towards regionalization of social and economic processes and local development factors are of particular importance [16].

For the analysis of the situation with civic engagement we used data obtained from the sociological survey of the Vologda Research Center of the Russian Academy of Sciences (VolRS RAS). The face-to-face survey was conducted by using a questionnaire containing 54 questions in autumn of 2019 in two large cities (Vologda, Cherepovets) and 13 municipal centers of the Vologda Oblast: Sheksna, Gryazovets, Sokol, Veliky Ustyug, Chagoda, Belozersk, Tarnogsky Gorodok, Shuyskoye, Kirillov, Ustyuzhna, Babaevo, Vozhega, Nikolsk. The assessment was conducted at the respondents' place of residence. The sample 
size was 1900 people aged 18 and older (604 respondents were from two large cities, 1296 were from the municipal centers). Sampling error does not exceed 3\%. Vologda region is a typical region in the country based on its main socio-economic characteristics; therefore, we consider it as an example.

\subsection{Limitations}

Theoretical concepts of the "third" sector are still developing in Russia and scholars mainly rely on the works of foreign colleagues and use the definition given by Lester M. Salamon and his colleagues at Johns Hopkins Center for Civil Society Studies [17]. Despite the growing importance of the nonprofit sector in Russian regions, there are several weak points regarding its formal development that should be mentioned. Firstly, according to the definition given in national legal acts, governmental institutions are part of the third sector. This fact causes certain difficulties while analyzing statistical data on nonprofit entities and leads to conceptual problems [18]. Secondly, the variety of legal forms (more than 30) [19] and the fact that several governmental institutions are responsible for different types of NPOs, also lead to difficulties in interpreting the situation concerning the development of the nonprofit sector in the country. Partly, this problem is solved with the appearing of a recent phenomenon in the legislative system - socially oriented nonprofit organizations (SONPO). They make a core of the Russian nonprofit sector as about $60 \%$ of Russian NPOs are active in the social sphere, including education, social assistance and health [20]. For the aim of this research, we use statistical data available for SONPOs.

\section{$3 \quad$ Results}

The activities of nonprofit organizations are aimed at solving social problems and developing civil society in the country. At present, the nonprofit sector in Russian regions is characterized by developing trends but still has a long way to go. Thus, comparing nonprofit organizations' share in all establishments in the sphere of social assistance revealed that in the USA it comprises over $40 \%$ while in Russia it is approximately 3-6\%. The number of socially oriented nonprofit organizations steadily increases in Russia; however, it is still quite low. Therewith, the share of regional organizations decreases contributing to interregional differentiation. Table 1 shows the dynamics of SONPOs in Russia and Vologda region.

Tab. 1: Dynamics of SONPOs development in Russia

\begin{tabular}{|l|l|l|l|l|l|l|}
\hline Year & \multicolumn{3}{|l|}{ Number of SONPOs } & \multicolumn{2}{l|}{$\begin{array}{l}\text { Number of people receiving services } \\
\text { from SONPOs }\end{array}$} \\
\cline { 2 - 8 } & RF & $\begin{array}{l}\text { Vologda } \\
\text { region }\end{array}$ & $\begin{array}{l}\text { The share } \\
\text { of regional } \\
\text { SONPOs, } \\
\text { in \% }\end{array}$ & RF & $\begin{array}{l}\text { Vologda } \\
\text { region }\end{array}$ & $\begin{array}{l}\text { The share } \\
\text { of regional } \\
\text { SONPOs, } \\
\text { in \% }\end{array}$ \\
\hline 2017 & 142641 & 1465 & 1.03 & 35536819 & 257366 & 0.72 \\
\hline 2016 & 143436 & 1752 & 1.22 & 31825253 & 271974 & 0.85 \\
\hline 2015 & 140031 & 1721 & 1.23 & 26319671 & 208747 & 0.79 \\
\hline 2014 & 132087 & 1754 & 1.33 & 23215642 & 208380 & 0.9 \\
\hline 2013 & 113237 & 1696 & 1.5 & 17882629 & 191201 & 1.07 \\
\hline
\end{tabular}

Source: own calculations based on the data from Federal State Statistics Service. Available at: https://fedstat.ru/

One of the key indicators of nonprofit organizations development is the dynamics in volunteering activities. As studies show, the better developed nonprofit sector is, the higher the level of volunteering is [21]. In our opinion, this rule can be applied vice versa - the stronger people feel their responsibility for the development of their community, the more 
they are engaged in public activities, the faster the formation of nonprofit sector is. The analysis of statistical data showed that the share of people engaged in volunteer activities in Russia in general is approximately $2 \%$, while in Russian regions it is even less (table 2).

Tab. 2: Number of volunteers

\begin{tabular}{|c|c|c|c|c|c|c|}
\hline \multirow{2}{*}{ Year } & \multicolumn{2}{|c|}{ Russian Federation } & \multicolumn{3}{c|}{ Vologda region } \\
\cline { 2 - 7 } & Population & $\begin{array}{c}\text { Average number } \\
\text { of volunteers }\end{array}$ & $\boldsymbol{\%}$ & Population & $\begin{array}{c}\text { Average number } \\
\text { of volunteers }\end{array}$ & $\%$ \\
\hline 2017 & 146804372 & 2710023 & 1.9 & 1180300 & 17000 & 1.4 \\
\hline 2018 & 146880432 & 2937318 & 2.0 & 1172200 & 18655 & 1.6 \\
\hline
\end{tabular}

Source: Own calculations based on the data from http://www.statdata.ru/russia and Federal State Statistics Service available at https://fedstat.ru/

In order to reveal reasons of weak volunteering activities, we analyzed the results of a survey conducted in 2019 by the Vologda Research Center of the Russian Academy of Sciences on the people's attitude toward their engagement in public life. The survey showed that $19.6 \%$ of the respondents did not participate in the community life and only 5.4\% of them evaluate their participation as active. $86.1 \%$ of respondents did not work as a volunteer within the last year. The answers to the question "Did you have to initiate collective actions during the last 12 months to ...?" confirmed that the majority of respondents are unengaged (fig.1), but they are ready to engage in community life, however only on financial terms (fig. 2).
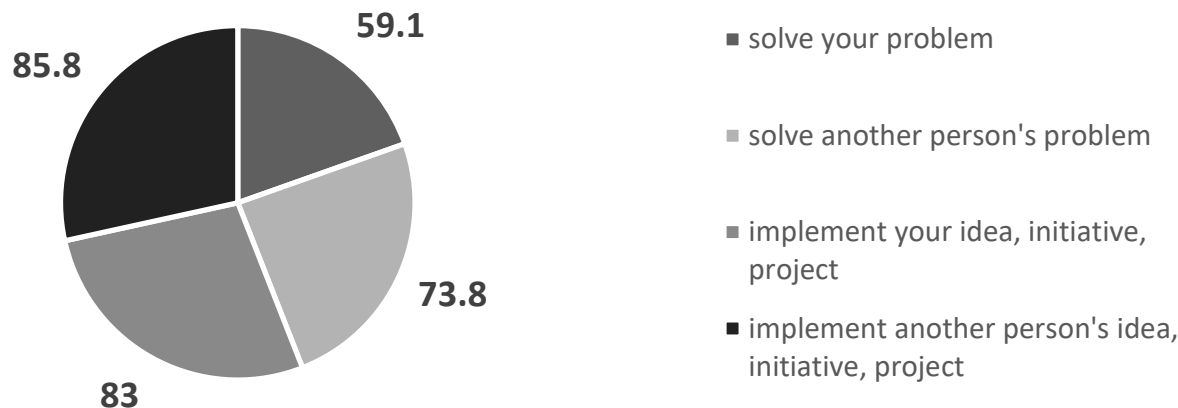

Source: VolRC RAS survey, 2019

Fig. 1: Dynamics of the answer "no" to the question "Did you have to initiate collective actions during the last 12 months to ...?" (in \% of respondents" number)

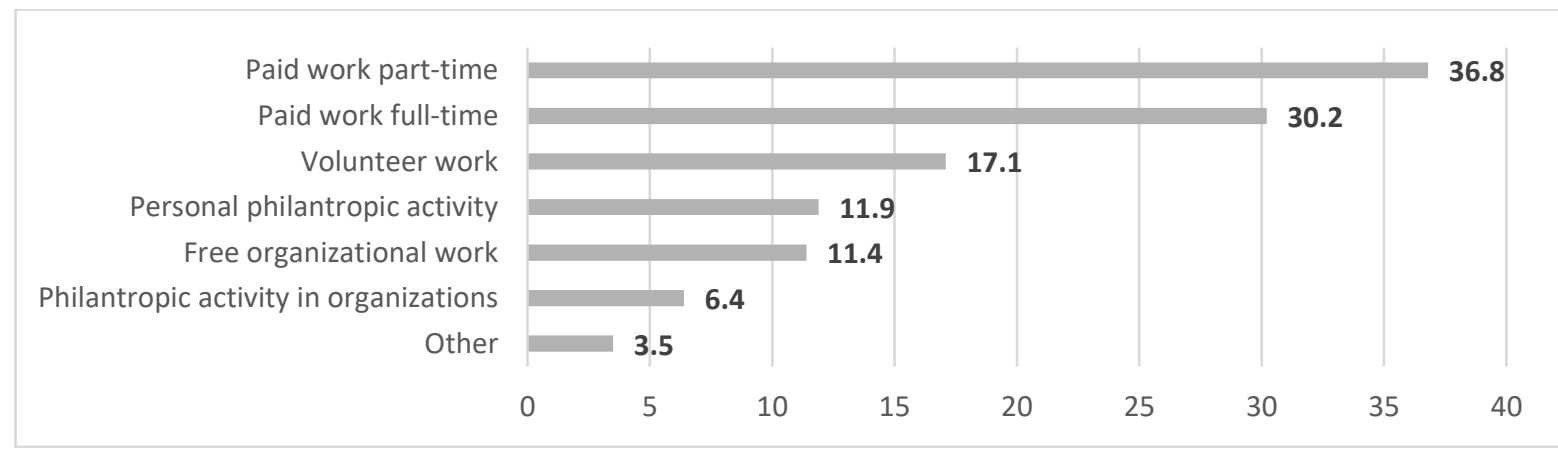

Source: VolRC RAS survey, 2019

Fig. 2: Distribution of the answers to the question "What forms of participation in public life can be acceptable for you?" in \%

In most cases, the activities of volunteers are associated with the work of nongovernmental nonprofit organizations, which act as initiators, organizers and regulators of actions aimed at solving socially significant problems of the population. The participation of citizens in the 
activities of public associations is an important indicator reflecting the level of civic participation as a whole. The results of the survey have revealed that NPOs in Russia are still in the process of gaining recognition (table 3 ).

Tab. 3: Distribution of the respondents' answers

\begin{tabular}{|l|r|}
\hline Question & Share of answers, in \% \\
\hline In cities and towns people form nonprofit organizations. Do you know about them? \\
\hline In your town & 8.7 \\
\hline Yes, I know & 44.7 \\
\hline I have heard something & 46.6 \\
\hline No, I do not know & 5.1 \\
\hline In your region & 40.8 \\
\hline Yes, I know & 54.1 \\
\hline I have heard something & 7.5 \\
\hline No, I do not know & 38.6 \\
\hline In Russia & 53.9 \\
\hline Yes, I know & \\
\hline I have heard something & \\
\hline No, I do not know & 79.5 \\
\hline $\begin{array}{l}\text { Do you know, are you a member of, or do you participate in any events organized by } \\
\text { nonprofit organizations? }\end{array}$ & 77.3 \\
\hline I do not know any & \\
\hline I am not a member & \\
\hline I do not participate &
\end{tabular}

Source: VolRC RAS survey, 2019

The survey included a question "What stops you from participating in community life, in events of nonprofit organizations?" The answers to this question allowed us to determine the main reasons of people's inertness. Thus, the majority of the respondents do not participate in public life due to the lack of free time $(36.3 \%)$ or interest in such activities $(27 \%)$. Some answers indicate that people are not certain if they are fit (healthy) enough to engage in public life $(20.1 \%)$, if they have necessary skills $(12.4 \%)$, if there is any help from this engagement $(11.3 \%)$. Also, it should be noted that some respondents consciously deny civic engagement because it does not help solve their individual problems and those of their relatives $(8.6 \%)$ or does not offer them opportunities for personal development $(9 \%)$. One of the important reasons of inactiveness is that people do not know where to go and do not have any information $(4.8 \%)$.

\section{Discussion}

The results obtained within the framework of this research confirm previous findings to a certain extent. Various studies demonstrate that nonprofit organizations have limited use and people are more likely to seek help from family and friends [22; 23]. Representatives of the third sector often blame unfavorable external environment for such failures. However, based on the paper by a Russian researcher Zadorin I. V. and his colleagues [24], there are four levels of interaction affecting the development of the sector: between nonprofits and citizens, nonprofits and authorities, nonprofits and business, and internal issues of nonprofits. The relationship with authorities includes general attitudes of the latter regarding nonprofit organizations, forms and principles of interaction, efficiency of participation in the processes of decision-making. Relationship with business structures can be seen in the degree of motivation for interaction, opportunities for self-organization, and activity of the business in 
social projects. Relationship between nonprofit organizations and individuals include understanding the role of NPOs, motivation to participate, and civic education. Internal issues of the third sector are related to environmental restrictions and opportunities, coordination and partnership, professionalism and competence, and the ability to recruit. In the Russian case, it is obvious that all four aspects should be significantly improved. The results of this study clearly show that despite the positive trend in the development of the nonprofit sector in the country, one of the most important challenges is the low level of civic engagement, and it puts at risk the main goal of nonprofit organizations which is to address public concerns and ensure high living standards of the population.

The challenges related to the decreasing civic engagement are characteristic for European countries as well. As the results obtained within the framework of the project "Third Sector Impact" show, $73 \%$ of the surveyed organizations regard limited public awareness as a serious problem [25, p. 4]. Nonprofit organizations face problems recruiting volunteers and board members; citizens are becoming more constrained and hesitant to take up responsibility, especially for long periods of time. Trends in the development of the nonprofit sector in Eastern Europe are quite similar to those in Russia: despite the general upward trend in terms of organizational growth, the membership base is shrinking and social anchorage is still limited [26]. A human resource shortage is a major challenge for local communities as it is rather difficult to engage professionals in voluntary activities on a regular basis. This results in problems with media coverage, public image, fundraising challenges, and recognition within different part of the society [27, p. 10]. Therefore, in our opinion, priority attention should be paid to the activities that allow overcoming challenges related to people' engagement and participation in community life.

\section{Conclusion}

Summarizing the results of the study, we defined three groups of barriers hindering a more active civic engagement and consequently a more rapid development of the Russian nonprofit sector:

1. Motivation barriers include lack of time or information. Nonprofit organizations have difficulties with finding not only initiative people, but also those who are simply open to participation in public activities. Experts point to the dominance of paternalistic attitudes, deep doubts that something could be demanded from the authorities. In order to overcome these barriers, local authorities should create working mechanisms for people to communicate and realize their ideas; for example, special online and offline platforms where they can meet and discuss initiatives. Public service announcements can help promote and spread information about nonprofit organizations and their activities, form new habits and practices of engagement. In addition to it, employers should be encouraged to provide opportunities for employees. It can concern working hours or financial means. At the same time, employers should also be rewarded for this behavior (tax reduction, special conditions within government contracts, etc.).

2. Hesitation barriers include insecurities connected with skills, health or difference people can make if they participate in public life. This barrier suggests that people are ready to engage and therefore it is necessary to give them this opportunity. In our opinion, the key players in such cases are local nonprofit organizations. Being close to potential activists they know what, when, where is needed, and how different people can contribute to the community. One of the challenges, however, is the fact that activists and leaders of NPOs often do not have knowledge how to engage these people as for the most part they belong to the category of "intuitive leaders". They have nowhere to acquire skills in organizing joint actions, negotiation skills, public speaking, preparing appeals, etc. 
3. Inward-focused barriers include lack of interest or concentration on one's own life goals and problems. Weak interest in social activity is shown by people who are career-oriented and consider social activities costly and unpromising. However, we believe that the increase of mass-media attention to civic engagement practices will positively affect people's attitude towards this phenomenon.

Studies show that at the initial stage, nonprofit organizations always face the rigidity of the existing political, administrative, business structures, and people. At the same time, with organizational development, mobilization of resources and the accumulation of experience, the influence of NPOs on the society increases. As our research reveals, the Russian nonprofit sector is still developing and meets many challenges. They include not only problems in cooperation with the authorities or business but also difficulties in civic engagement; and in our opinion, this is the most important issue that has to be addressed. Under present circumstances in Russia, when government is working on the nonprofit sector development at least as much as the sector itself, the common goal is teaching people to be initiative citizens, explaining ways to express opinions and creating opportunities for sharing ideas.

\section{Acknowledgements}

The study was supported by the Russian Foundation for Basic Research (research project No. 19-011-00724 A «Barriers to civic participation and mechanisms for their overcoming at the regional level»).

\section{Literature}

[1] MERSIANOVA, I. V.; BENEVOLENSKI, V. B. NPOs as social services providers: Organizational weaknesses verifying. Public Administration Issues. 2017, Issue 2, pp. 83-104.

[2] SHABUnOVA, A. A.; KOSYGINA, K. E.: Public Administration Issues in the Development of the Non-Profit Sector at the Regional Level. Economic and Social Changes: Facts, Trends, Forecast. 2019, Vol. 12, Issue 4, pp. 86-103. DOI: $\underline{10.15838 / \text { esc.2019.4.64.6 }}$

[3] GROMOVA, M. N.; MERSIYANOVA, I. V.: State support of the non-profit sector and issue of estimation of its efficiency. Civil Society in Russia and Abroad. 2016, Issue 1, pp. 39-44.

[4] KRASNOPOLSKAYA, I.; SKOKOVA, Yu.; PAPE, U.: Government-Nonprofit Relations in Russia's Regions: An Exploratory Analysis. VOLUNTAS: International Journal of Voluntary and Nonprofit Organizations. 2015, Issue 26, pp. 2238-2266. DOI: $\underline{10.1007 / \mathrm{s} 11266-015-9654-3}$

[5] KNYAZEVA, M. V.: Functioning of non-commercial organizations in the Russian Federation and their influence on social-economic processes. Tomsk State University Journal. 2011, Issue 344, pp. 141-144.

[6] TARASENKO, A.: Nekommercheskii sektor v ES $i$ Rossii (Nonprofit Sector in the EU and Russia). 2015. 224 p.

[7] VDOVINA, G. K.: Prospects of the development of the nonprofit sector in Russia and its regions. Eurasian Union of Scientists. 2015, No. 10-5 (19), pp. 32-34.

[8] YAKOBSON, L. I.; SANOVICH, S. V.: The Changing Models of the Russian Third Sector: Import Substitution Phase. Journal of Civil Society. 2010, Vol. 6, Issue 3, pp. 279-300. DOI: 10.1080/17448689.2010.528951 
[9] MEDVEDEVA, N. V.; FROLOVA, E. V.: Trends in the development of the nonprofit sector in the Russian Federation under the conditions of interregional differentiation. Proceedings of the Afanasyev Readings. 2018, Vol. 24, Issue 3, pp. 22-28.

[10] MOSKOVSKAYA, A. A.: Incentives and Barriers to Engaging Non-State Providers in the Provision of Public Social Services: Russian and Foreign Experience. Public Administration Issues. 2018, Issue 3, pp. 88-116.

[11] SALAMON, L. M.: Partners in Public Service: The Scope and Theory of GovernmentNonprofit Relations. In: Walter, W (ed.), Powell The Nonprofit Sector: A Research Handbook, . New Haven, CT: Yale University Press. 1987, pp. 99-117.

[12] ENJOLRAS, B.; SALAMON, L. M.; SIVESIND, K. H.; ZIMMER, A.: The Third Sector as a Renewable Re-source for Europe: Concepts, Impacts, Challenges and Opportunities. 2018. 196 p. DOI: 10.1007/978-3-319-71473-8

[13] ACHESON, N.: Service Delivery and Civic Engagement: Disability Organizations in Northern Ireland. VOLUNTAS: International Journal of Voluntary and Nonprofit Organizations. 2001, Issue 12, pp. 279-283. DOI: 10.1023/A:1012395402144

[14] NAKAMURA, L.: Cybertypes: Race, Ethnicity, and Identity on the Internet. New York: Routledge, 2002. ISBN 978-0-415-93836-5.

[15] ANHEIER, H. K.: Nonprofit Organizations. Theory, Management, Policy. Routledge, 2014. eBook ISBN9781315851044. DOI: $\underline{10.4324 / 9781315851044}$

[16] LAZHENTSEV, V. N.: Theory of territorial development and practice of territorial planning. Issues of Territorial Development. [online]. 2014, Vol. 18, Issue 8. Available from WWW: http://vtr.vscc.ac.ru/article/1433

[17] SALAMON, L. M.; ANHEIER, H. K.; LIST, R.; TOEPLER, S.; SOKOLOWSKI, W. and associates: Global Civil Society Dimensions of the Nonprofit Sector. The Johns Hopkins Center for Civil Society Studies. Baltimore, MD, 1999. 512 p.

[18] MYSIN, S. V.: Urgent problems of the terminology in the sphere of nonprofit organizations in modern Russian law. BSU Bulletin. 2014, Issue 2, pp. 233-236.

[19] ARTAMONOVA, A. S.: Assessment of the state of the nonprofit organizations sector. Social Area. [online]. 2017, Vol. 10, Issue 3. Available from WWW: http://socialareajournal.ru/article/2313

[20] SKOKOVA, Yu.; PAPE, U.; KRASNOPOLSKAYA, I.: The Non-profit Sector in Today's Russia: Between Confrontation and Co-optation. Europe-Asia Studies. 2018, Vol. 70, Issue 4. DOI: 10.1080/09668136.2018.1447089

[21] ARON, R.: Les Etapes de la Pensee Sociologique. Translated into Russian. P. S. Gurevich (ed.), Moscow, 1992.

[22] STAGNER, M.; RICHMAN, H.: Help-Seeking and the Use of Social Service Providers by Welfare Families in Chicago. Chicago, Chapin Hall Center for Children, 1986.

[23] EDIN, K.; LEIN L.: Making Ends Meet: How Single Mothers Survive Welfare and LowWage Work. New York: Russell Sage Foundation, 1997.

[24] ZADORIN, I. V.; ZAYTSEV, D. G.; KLIMOV, I. A.: Civil participation in Russia: Cartography of problems and solutions. Politeia, 2011, Issue 1, pp. 98-116. DOI: $10.30570 / 2078-5089-2011-60-1-98-116$ 
[25] ZIMMER, A.; PAHL, B.: Learning from Europe: Report on Third Sector Enabling and Disabling Factors. TSI Comparative Report No. 1, Seventh Framework Programme (grant agreement 613034). European Union. Brussels: Third Sector Impact. 2016. 30 p.

[26] BEŽOVAN, G.; MATANČEVIĆ, J.; BATURINA, D.: Identifying External and Internal Barriers to Third Sector Development in Croatia. TSI National Report Series No. 5. Seventh Framework Programme (grant agreement 613034). European Union. Brussels: Third Sector Impact. 2016. 52 c.

[27] LEŚ, E.; NAŁĘCZ, S.; PIELIŃSKI, B.: Third sector barriers in Poland. TSI National Report Series No. 7. Seventh Framework Programme (grant agreement 613034. European Union. Brussels: Third Sector Impact. 2016. 46 c. 


\section{VÝVOJ NEZISKOVÉHO SEKTORU V RUSKÝCH REGIONECH: HLAVNÍ VÝZVY}

Cílem tohoto článku je identifikovat hlavní překážky bránící rozvoji neziskového sektoru v ruských regionech. Výzkum je založen na přesvědčení, že jeho rozvoj je pro regionální sociálně-ekonomický systém zásadní a závisí na občanské angažovanosti. Výsledky analýzy dostupných statistických údajů a sociologického průzkumu provedeného v jednom z ruských regionů ukazují, že podíl Rusů zapojených do dobrovolnických aktivit je nízký; více než $80 \%$ populace se neúčastní veřejných aktivit; méně než $10 \%$ má určité znalosti o fungujících neziskových organizacích. Studie umožnila identifikovat tři skupiny hlavních překážek a formulovat některá doporučení pro jejich překonání.

\section{DiE ENTWICKLUNG DES GEMEINNÜTZIGEN SEKTORS IN RUSSISCHEN REGIONEN: HAUPTHERAUSFORDERUNGEN}

Dieser Artikel zielt darauf ab, die Haupthindernisse zu identifizieren, die seine Entwicklung in russischen Regionen behindern. Die Forschung basiert auf der Überzeugung, dass die Entwicklung des gemeinnützigen Sektors für das regionale sozioökonomische System von entscheidender Bedeutung ist und vom bürgerschaftlichen Engagement abhängt. Die Ergebnisse einer Analyse der verfügbaren statistischen Daten und einer soziologischen Untersuchung in einer der russischen Regionen zeigen, dass der Anteil der Russen, die sich freiwillig engagieren, gering ist. über $80 \%$ der Bevölkerung nehmen nicht an öffentlichen Aktivitäten teil; Weniger als $10 \%$ haben definitive Kenntnisse über gemeinnützige Organisationen. Die Studie ermöglichte es, drei Gruppen der Haupthindernisse zu identifizieren und einige Empfehlungen für deren Überwindung zu formulieren.

\section{ROZWÓJ SEKTORA NON-PROFIT W REGIONACH ROSYJSKICH: GŁÓWNE WYZWANIA}

Artykuł ma na celu zidentyfikowanie głównych barier utrudniających jego rozwój w regionach Rosji. Badanie opiera się na przekonaniu, że rozwój sektora non-profit ma kluczowe znaczenie dla regionalnego systemu społeczno-gospodarczego i zależy od zaangażowania obywatelskiego. Wyniki analizy dostępnych danych statystycznych oraz badania socjologicznego przeprowadzonego w jednym z regionów Rosji pokazują, że udział Rosjan w wolontariacie jest niski; ponad 80\% ludności nie uczestniczy w działaniach publicznych; mniej niż 10\% ma określoną wiedzę na temat pracy organizacji non-profit. Badanie pozwoliło na wyodrębnienie trzech grup głównych barier i sformułowanie zaleceń dotyczących ich pokonywania. 